\title{
Pengaruh Doping Ni(II) pada Sintesis UiO-66 secara Solvotermal dengan Modulator Asam Format
}

\author{
Afifah Rosyidah, Adhisti Widdhiantari dan Ratna Ediati \\ Jurusan Kimia, Fakultas Matematika dan Ilmu Pengetahuan Alam, Institut Teknologi Sepuluh Nopember (ITS) \\ Jl. Arief Rahman Hakim, Surabaya 60111 Indonesia \\ e-mail:afifah@chem.its.ac.id
}

\begin{abstract}
Abstrak-Sintesis UiO-66 dengan doping 10\% Ni(II) telah berhasil dilakukan menggunakan metode solvotermal dengan modulator asam format pada suhu $120^{\circ} \mathrm{C}$ selama 24 jam. Padatan hasil sintesis dianalisis menggunakan XRD, FTIR, SEM-EDX, TGA, dan adsoprsi-desorpsi isotermal $\mathrm{N}_{2}$. Difraktogram XRD padatan hasil sintesis memiliki dua puncak utama pada sudut $2 \theta=7,4^{\circ}$ dan $8,5^{\circ}$ yang sesuai dengan difraktogram UiO-66 standar. Spektra FT-IR menunjukkan bahwa padatan hasil sintesis memiliki pita-pita serapan karakteristik yang dimiliki material UiO-66.Foto SEM menunjukkan bahwapenambahan modulator asam format menghasilkan morfologi yang lebih besar. Hasil adsorpsi-desorpsi $\mathrm{N}_{2}$ menunjukkan bahwa luas permukaan BET meningkat menjadi 1.020,433 $\mathrm{m}^{2} / \mathrm{g}$ setelah doping $\mathrm{Ni}$ (II) dan penambahan modulator asam format. Namun doping $\mathrm{Ni}$ (II) dan penambahan modulator asam format menurunkan stabilitas termal UiO-66 menjadi $434^{\circ} \mathrm{C}$.
\end{abstract}

Kata Kunci--Sintesis UiO-66, doping Ni(II), modulator asam format.

\section{Pendahuluan}

Metal Organic Framework (MOF) merupakan polimer yang terbentuk dari ikatan koordinasi antara ion logam anorganik dengan ligan organik seperti karboksilat atau amina sehingga membentuk suatu kristal berpori yang berbeda dengan meterial berpori lainnya [1].Perbedaan tersebut menjadikan MOF sebagai material berpori kelas baru yang dapat diaplikasikan pada bidang industri diantaranya, untuk pemisahan dan penyimpanan gas serta katalis [2]. Keunggulan dari MOF terletak pada luas permukaannya yang besar strukturnya yang kristalin, densitasnya yang kecil serta ukuran porinya yang dapat diatur. Keragaman logam dan ligan organik dapat membentuk ukuran pori yang simetris dan luas permukaan yang besar sehingga memiliki kapasitas adsorpsi yang tinggi dan dapat diaplikasikaan untuk penyimpan gas $\mathrm{H}_{2}$ dan $\mathrm{CO}_{2}$ [3].Disamping semua keunggulan tersebut, MOF juga memiliki satu kekurangan utama yaitu stabilitas termalnya yang rendah.Kestabilan MOF bergantung pada atom pusat anorganik dan kekuataan ikatan kimia antara atom pusat anorganik dengan ligan yang terikat [4]. Untuk meningkatkan stabilitas termal pada MOF tersebut dapat dilakukan dengan meningkatkan bilangan koordinasi dari ion logam anorganik [5].

Pada sintesis MOF, ion logam dan ligan organik mempunyai peranan penting dalam pembentukan subkelas dari MOF karena apabila ion logam dan ligan organiknya diubah dengan jenis lain maka akan terbentuk subkelas MOF yang baru. Salah satu contoh subkelas MOF yang telah berhasil disintesis yaitu UiO-66. UiO-66 tersusun atas logam anorganik zirkonium $(\mathrm{Zr})$ dengan ligan organik benzendikarboksilat $\left(\mathrm{H}_{2} \mathrm{BDC}\right)$. $\mathrm{Zr}-\mathrm{BDC}$ (UiO-66) memiliki struktur 3-D oktahedral dengan diameter rongga $11 \AA$ Å serta tetrahedral dengan diameter rongga $8 \AA$ A. Penggunaan zirkonium (Zr) sebagai logam anorganik ini karena unsur tersebut termasuk dalam unsur golongan IV yang dapat berinteraksi kuat dengan oksigen yang terdapat pada linker sehingga dapat menjadi struktur anorganik yang stabil [6].

Aplikasi dari UiO-66 yang telah dilaporkan diantaranya adalah sebagai katalis dan penyimpan gas. Vermoortele dkk. [7] melaporkan bahwa Zr-BDC (UiO66) menunjukkan aktivitas katalitik dalam beberapa macam reaksi organik seperti kondensasi cross-aldol melalui penambahan ligan fungsional $\mathrm{NH}_{2}$ [7] dan 
asetilisasi benzaldehid dengan metanol [8]. Keunggulan UiO-66 dengan luas permukaannya yang besar telah diaplikasikan sebagai penyimpang gas $\left(\mathrm{H}_{2}, \mathrm{CO}_{2}, \mathrm{CH}_{4}\right)$.

Zhao dkk. [2] melaporkan bahwa UiO-66 telah berhasil disintesis dalam berbagai pelarut organik (metanol, etanol, aseton, dan DMF). Kristal oktahedral hasil sintesis dalam pelarut DMF memiliki luas permukaan terbesar yaitu $1358 \mathrm{~m}^{2} / \mathrm{g}$ dengan ukuran partikel 150-200 nm serta kapasitas penyimpanan hidrogen sebesar 3,35 wt\%.Selain itu, Abid dkk. [3] berhasil melakukan sintesis UiO-66 menggunakan metode solvotermal dan diaktivasi dengan perendaman menggunakan kloroform serta pengeringan dalam vakum. Hasil dari penelitian ini berupa material berukuran nano dengan ukuran partikel sebesar $100 \mathrm{~nm}$, luas permukaan sangat tinggi sebesar $1434 \mathrm{~m}^{2} / \mathrm{g}$, dan volume pori sebesar $0,654 \mathrm{~cm}^{3} / \mathrm{g}$. Kapasitas penyimpanan hidrogen optimum yang didapatkan yaitu sebesar $4,2 \mathrm{wt} \%$ pada suhu $77 \mathrm{~K}$ dan tekanan $6 \mathrm{Mpa}$.

Li dkk. [9] melaporkan bahwa metode sintesis langsung dengan penambahan modulator TEA pada MOF-5 menghasilkan material dengan luas permukaan $500,8 \mathrm{~m}^{3} / \mathrm{g}$, volume pori $0,19 \mathrm{~cm}^{3} / \mathrm{g}$ dan kapasitaspenyimpanan hidrogen sebesar 3,2 wt $\%$. Sedangkan MOF-5 yang disintesis dengan metode sintesis solvotermal tanpa penambahan TEA memiliki luaspermukaan $839,6 \mathrm{~m}^{2} / \mathrm{g}$, volume pori $0,34 \mathrm{~cm}^{3} / \mathrm{g}$ dan kapasitas penyimpanan hidrogen sebesar 3,6 wt \% .

Hal tersebut menunjukkan bahwa metode solvotermal merupakan metode terbaik dalam menghasilkan material dengan luas permukaan dan volume pori yang tinggi. Ren dkk [10] melaporkan bahwa penambahan modulator asam format pada UiO-66 dapat meningkatkan kapasitas penyimpanan hidrogen. Modulator asam format yang ditambahakn memiliki variasi $0,10,50$ dan 100 eq. Hasil sintesis UiO-66 dengan penambahan asam format 100 eq menunjukkan kapasitas penyimpanan hidrogen yang paling besar yaitu $1,5 \mathrm{wt} \%$ dengan luas permukaan BET sebesar $1367 \mathrm{~m}^{2} / \mathrm{g}$.

Selain memodifikasi metode sintesisnya, peneliti juga menambahkan logam seperti $\mathrm{Ni}, \mathrm{Pt}$, dan $\mathrm{Pd}$ pada sintesis UiO-66. Lee dkk. [11] meneliti pengaruh penambahan logam Pt pada material karbon aktif/MOF-5 untuk memperoleh kapasitas penyimpanan hidrogen yang tinggi. Dari penelitian tersebut diperoleh kapasitas penyimpanan hidrogen Pt-ACs-MOF-5 sebesar 2,3 wt \% pada suhu $298 \mathrm{~K}$ dan tekanan 100 bar. Peningkatan tersebut senilai 5 kali jika dibandingkan nilai kapasitas penyimpanan hidrogen ACs dan 3 kali jika dibandingkan dengan kapasitas penyimpanan hidrogen MOF-5. Oleh karena itu, disimpulkan bahwa penambahaan Pt dapat mengubah kapasitas penyimpanan hidrogen. Salah satu peneliti bernama Zubizarreta dkk. [12] melakukan doping $\mathrm{Ni}$ pada material karbon nanospheres. Metode yang digunakan yaitu metode impregnasi larutan berlebih dan pencampuran secara fisik. Jumlah nikel yang ditambahkan mempengaruhi peningkatan kapasitas penyimpanan hidrogen dari karbon. Sampel yang mengandung $\mathrm{Ni}$ sebesar 5 wt\% memiliki kapasitas penyimpanan hidrogen yang paling tinggi. Hal tersebut dikarenakan interaksi yang lebih besar antara nikel dengan pendukung sehingga menghasilkan aktivasi yang lebih tinggi dari padatan melalui efek spillover.

Yang dkk. [13] juga telah berhasil melakukan sintesis MOF-5 dengan doping Ni(II) menggunakan metode solvotermal yang menghasilkan material berukuran nano kristal. Pada rasio volume $\mathrm{C}_{2} \mathrm{H}_{5} \mathrm{OH}$ : $\mathrm{DMF}=4: 6$, dihasilkan luas permukaan Langmuir sebesar $3023 \mathrm{~m}^{2} / \mathrm{g}^{2}$, dan ketika konsentrasi reaktan untuk $\mathrm{H}_{2} \mathrm{BDC}$, $\mathrm{Zn}\left(\mathrm{NO}_{3}\right)_{2} \cdot 6 \mathrm{H}_{2} \mathrm{O}$ dan $\mathrm{Ni}\left(\mathrm{NO}_{3}\right)_{2} \cdot 6 \mathrm{H}_{2} \mathrm{O}$ ditingkatkan 0,8 $\mathrm{mM}$, luas permukaan Langmuir meningkat jadi 3204 $\mathrm{m}^{2} / \mathrm{g}^{2}$. Oleh karena itu, dapat disimpulkan bahwa doping $\mathrm{Ni}$ (II) pada MOF-5 dapat meningkatkan luas permukaan Ni-MOF-5.

Pengaruh doping Ni(II) pada sintesis ZIF-8 secara solvotermal telah dilaporkan oleh Yudianto dan Ediati [14] dengan variasi penambahan ion $\mathrm{Ni}^{2+}$ yaitu 5,10 , $15 \%$. Hasil dari penelitian tersebut menunjukkan bahwa doping $10 \% \mathrm{Ni}$ (II) menghasilkan kristalinitas tertinggi dan luas permukaan sebesar $1074,71 \mathrm{~m}^{2} / \mathrm{g}$.

Beberapa uraian diatas menunjukkan bahwa sintesis material UiO-66 dapat dipengaruhi oleh beberapa hal yaitu penambahan logam, metode sintesis, serta penambahan modulator. Oleh sebab itu pada penelitian ini peneliti akan menggabungkan 3 kompenen tersebut. Logam yang dipilih untuk ditambahkan yaitu logam nikel karena memiliki kemampuan untuk meningkatkan luas permukaan material.Kemudian ditambahkan pula modulator asam format dan disintesis menggunakan metode sintesis solvotermal. Adapun rasio perbandingan $\mathrm{Zr} / \mathrm{Ni}$ yang digunakan yaitu $10 \%$ serta variasi konsentrasi asam format sebesar 10 dan 100 eq. Material Ni-UiO-66 kemudian dikarakterisasi dan dianalisis menggunakan $X$-Ray diffraction(XRD) yang berfungsi untuk menentukan komposisi fasa kristal, struktur kristal, dan kristalinitas, Thermal Gravimetry Analysis (TGA) yang berfungsi untuk menentukan stabilitas termal, selain itu untuk menentukan ikatan yang terdapat pada UiO-66 dan Ni-UiO-66 menggunakan Spektrofotometer Fourier Transform Infrared (FTIR) dan SEM untuk mengetahui morfologi, komposisi unsur yang terdapat dalam senyawa, serta adsorpsi nitrogen untuk mengetahui luas permukaan dan ukuran pori hasil sintesis.

\section{Percobaan}

\subsection{Alat dan Bahan}

Dalam penelitian ini peralataan yang dibutuhkan antara lain,pengaduk magnetik, pipet tetes,botol timbang, botol reaksi, botol vial, pompa vakum, peralatan gelas kimia, gelas ukur, neraca 
analitik, botol duran, oven, spektrofotometer FTIR (8400S Shimadzu), Scanning Electron Microscope (SEM-Zeiss, EVO MA10), X-Ray diffraction (XRD) (XRD-JEOL),Surface Area Analyzer,instrumen analisis termogravimetri (TGA-METTLER TELEDO). Sedangkan bahan yang digunakan dalam penelitian ini antara lain, N,N'-dimetilformida (DMF, Merck, 99,8\%), Zirkonium tetraklorida $\left(\mathrm{ZrCl}_{4}, \quad\right.$ Sigma-Aldrich, $\left.\quad 99 \%\right)$, 1,4-asam benzendikarboksilat (BDC, Sigma-Aldrich, 99\%), Nikel nitrat heksahidrat $\left(\mathrm{Ni}\left(\mathrm{NO}_{3}\right)_{2} \cdot 6 \mathrm{H}_{2} \mathrm{O}\right.$, SigmaAldrich, 99\%), Asam format ( $\mathrm{HCOOH})$, Kloroform $\left(\mathrm{CHCl}_{3}\right.$, Merck, 99,9\%).

\subsection{Prosedur Kerja}

Pada prosedur penelitian untuk sintesis UiO-66 dilakukan dengan modifikasi perbandingan mmol 2 $\mathrm{ZrCl}_{4}$ : 2 BDC : 778,22 DMF. $\mathrm{ZrCl}_{4}$ dan BDC dilarutkan dalam $60 \mathrm{~mL}$ DMF dalam botol reaksi tertutup, kemudian diaduk menggunakan pengaduk magnetik selama 30 menit dan direaksikan dalam oven pada suhu $120{ }^{\circ} \mathrm{C}$ selama 24 jam. Campuran yang telah terbentuk didinginkan selama 24 jam pada suhu ruang, kemudian endapan yang terbentuk dipisahkan dengan cara dekantasi. Endapan yang diperoleh direndam dalam $30 \mathrm{~mL}$ DMF selama 24 jam selanjutnya dilakukan perendaman kembali menggunakan $30 \mathrm{~mL}$ kloroform selama 24 jam sebanyak dua kali. Endapan hasil perendaman kemudian dikeringkan dalam kondisi vakum pada suhu $90{ }^{\circ} \mathrm{C}$ selama 2,5 jam. Prosedur sintesis UiO66 doping $\mathrm{Ni}$ (II) dan modulator asam format hampir sama dengan sintesis UiO-66. Namun, perbedaan dari kedua sintesis UiO-66 dan UiO-66 doping Ni(II) dan modulator asam format adalah rasio komposisi bahan untuk masing-masing reaktan yang dapat dilihat pada Tabel 1. Endapan hasil sintesis yang diperoleh selanjutnya dikarakterisasi menggunakan difraktomer Sinar-X (XRD), spektrofotometer FTIR, Scanning Electron Microscope (SEM), Thermo Gravimetry Analyzer (TGA), dan Adsorpsi desorpsi $\mathrm{N}_{2}$. C. Karakterisasi

Karakterisasi dengan Difraksi Sinar-X (XRD) digunakan untuk mengetahui struktur kristal dan kristalinitas pada material. Pola hamburan XRD didapatkan dengan difraktometer sinar-X menggunakan radiasi $\mathrm{Cu} \mathrm{Ka}(\lambda=1,5406 \AA)$ dengan sudut $2 \theta$ sebesar $5-50^{\circ}$ dan interval scan sebesar $0,02^{\circ}$.

Karakterisasi dengan FTIR digunakan untuk mengetahui gugus-gugus fungsi atau ikatan yang terdapat pada material. Spektra FTIR dideteksi pada bilangan gelombang $650-4000 \mathrm{~cm}^{-1}$ dengan resolusi $4 \mathrm{~cm}^{-1}$ yang disiapkan melalui penggerusan dengan $\mathrm{KBr}$ pada perbandingan sampel : $\mathrm{KBr}=1: 99$.

Karakterisasi dengan Scanning Electron Microscope (SEM) digunakan untuk mengetahui morfologi dan ukuran partikel pada material. Karakterisasi dilakukan dengan meletakkan sampel pada permukaan sampel holder yang telah berisi carbon type,kemudian dilakukan coating berlapis emas agar permukaan sampel dapat terdeteksi oleh SEM.

Tabel 1. Komposisi Bahan Sintesis

\begin{tabular}{|c|c|c|c|c|c|}
\hline Sampel & $\underset{(\mathrm{g})}{\mathrm{ZrCl}_{4}}$ & $\begin{array}{l}\mathrm{Ni}\left(\mathrm{NO}_{3}\right)_{2} . \\
6 \mathrm{H}_{2} \mathrm{O}(\mathrm{g})\end{array}$ & $\begin{array}{c}\text { BDC } \\
(\mathrm{g})\end{array}$ & $\begin{array}{c}\text { HCO } \\
\text { OH } \\
(\mathbf{g})\end{array}$ & $\begin{array}{l}\text { DMF } \\
(\mathrm{mL})\end{array}$ \\
\hline UiO-66 & 0,4661 & - & 0,3323 & - & 60 \\
\hline $\begin{array}{l}\text { UiO- } 66+10 \text { eq } \\
\text { HCOOH }\end{array}$ & 0,4661 & - & 0,3323 & 0,828 & 60 \\
\hline $\begin{array}{l}\mathrm{UiO}-66+ \\
\text { 100eq } \mathrm{HCOOH}\end{array}$ & 0,4661 & - & 0,3323 & 8,28 & 60 \\
\hline Ni-UiO-66 & 0,4195 & 0,0581 & 0,3323 & - & 60 \\
\hline $\begin{array}{l}\mathrm{Ni-UiO}-66+ \\
\text { 10eq HCOOH }\end{array}$ & 0,4195 & 0,0581 & 0,3323 & 0,828 & 60 \\
\hline $\begin{array}{l}\mathrm{Ni}-\mathrm{UiO}-66+ \\
\text { 100eq HCOOH }\end{array}$ & 0,4195 & 0,0581 & 0,3323 & 8,28 & 60 \\
\hline
\end{tabular}


Karakterisasi dengan Thermal Gravimetri Analyzer (TGA) digunakan untuk mengetahui stabilitas termal pada material. Karakterisasi dilakukan pemanasan sampel dalam holder pada suhu $50-800{ }^{\circ} \mathrm{C}$ dengan laju $10{ }^{\circ} \mathrm{C} /$ menit dibawah aliran gas nitrogen.

Karakterisasi dengan Adsorpsi Isoterm $\mathrm{N}_{2}$ digunakan untuk mengetahui luas permukaan, volume pori dan ukuran distribusi pori pada material dengan suhu $77 \mathrm{~K}$.

\section{HASIL DAN PEMBAHASAN}

\subsection{Sintesis UiO-66 dan Ni-UiO-66 pada Beberapa Variasi Penambahan Modulator Asam Format}

Material UiO-66 telah berhasil disintesis dengan menggunakan metode solvotermal dengan perbandingan mol yaitu $2 \mathrm{mmol} \mathrm{ZrCl}_{4}$ : $2 \mathrm{mmol}$ BDC : 778,22 mmol DMF.

Sintesis material UiO-66 dilakukan dengan mereaksikan sebanyak $0,4661 \mathrm{~g} \mathrm{ZrCl}_{4}, 0,3323 \mathrm{~g}$ BDC dan $60 \mathrm{~mL}$ DMF didalam botol duran tertutup dan diaduk menggunakan magnetic stirrer selama 30 menit. Setelah pengadukan, campuran menjadi homogen.Campuran tersebut kemudian dipanaskan dalam oven selama 24 jam pada suhu $120{ }^{\circ} \mathrm{C}$. Pada penelitian ini dilakukan penambahan ion $\mathrm{Ni}$ (II) dan modulator asam format pada material UiO-66. Sintesis Ni-UiO-66 dengan penambahan modulator dilakukan sesuai tahapan pada sintesis UiO-66, tapi perbedaannya yaitu penambahan $\left(\mathrm{Ni}\left(\mathrm{NO}_{3}\right)_{2} \cdot 6 \mathrm{H}_{2} \mathrm{O}\right)$ dan asam format sebelum proses pengadukan.

Setelah proses pemanasan, campuran yang awalnya homogen berubah menjadi dua fasa yaitu endapan putih dan filtrat bening. Campuran tersebut kemudian didiamkan pada suhu ruang selama 24 jam dan selanjutnya didekantasi untuk memisahkaan filtratnya. Pencucian pertama dilakukan dengan menggunakan DMF selama 24 jam yang bertujuan untuk melarutkan sisa reaktan yang tidak bereaksi, kemudian dilanjutkan pencucian dengan kloroform sebanyak dua kali masing-masing 24 jam untuk melarutkan DMF dan BDC yang masih terjebak dalam kerangka UiO-66 dan Ni-UiO-66. Perlakuan tersebut sesuai dengan penelitian yang telah dilaporkan oleh Abid dkk.[3] yaitu proses aktivasi menggunakan kloroform dapat menghasilkan volume pori dan luas permukaan yang lebih tinggi tanpa mempengaruhi struktur kerangka Zr-BDC.

Setelah proses pencucian selesai, endapan yang telah dicuci kemudian dikeringkaan dalam kondisi vakum. Proses pengeringan dilakukan dalam kondisi vakum pada suhu $90{ }^{\circ} \mathrm{C}$ selama $2,5 \mathrm{jam}$. Tujuan pengeringan dalam vakum tersebut yaitu untuk meningkatkan porositas padatan hasil sintesis dengan membebaskan sisa-sisa pelarut yang masih terperangkap dalam pori. Kelarutan reaktan pada masing-masing sintesis dapat dilihat dari filtrat pertama hasil sintesis ketika belum dilakukan proses pencucian. Filtrat yang jernih menunjukkan bahwa kelarutan reaktan tinggi, endapan hasil reaksi yang diperoleh pun akan maksimal. Namun pada penelitian ini semakin keruh filtrat semakin banyak padatan yang diperoleh hal ini dimungkinkan kekeruhan tersebut adalah ligan atau logam yang berlebih, sehingga tidak membentuk frameworks.Padatan putih yang telah kering kemudian ditimbang untuk mengetahui massa dari hasil masing-masing sintesis. Massa padatan UiO66 hasil sintesis yaitu $0,585 \mathrm{~g}$, sedangkan massa $\mathrm{UiO}-66+10$ eq $\mathrm{HCOOH}, \mathrm{UiO}-66+100$ eq $\mathrm{HCOOH}$ berturut-turut sebesar 0,40 dan $0,45 \mathrm{~g}$. Sementara itu massa Ni-UiO-66, Ni-UiO-66 + 10 eq $\mathrm{HCOOH}$, Ni-UiO-66 + 100 eq $\mathrm{HCOOH}$ berturutturut yaitu 0,54, 0,60 dan 0,64 g. Penambahan modulator asam format turut mempengaruhi massa padatan hasil sintesis. Massa padatan hasil sintesis UiO-66 setelah ditambahkan modulator asam format mengalami penurunan namun setelah itu naik ketika ditambahkan lagi dengan ekuivalen yang lebih tinggi. Sedangkan pada sintesis Ni-UiO-66, massa hasil padatan setelah ditambahkan modulator asam format mengalami kenaikan seiring dengan kenaikan ekuivalen asam format yang ditambahkan.

\subsection{Karakterisasi Padatan Hasil Sintesis Difraksi Sinar-X(XRD)}

Karakterisasi dengan difraktometer Sinar-X (XRD) dilakukan untuk mengetahui tingkat kristalinitas, struktur dan kemurnian dari padatan hasil sintesis.Hasil karakterisasi ini berupa puncakpuncak karakteristik utama dari UiO-66 dengan intensitas yang bervariasi, dimana hasil tersebut kemudian dibandingkan dengan difraktogram UiO66 standar.

Difragtogram hasil sintesis seperti yang ditampilkan pada Gambar 1 menunjukkan bahwa puncak-puncak difraksi muncul pada sudut $2 \theta$ sekitar 7,4 dan $8,5^{\circ}$. Dua puncak difraksi tersebut muncul pada semua modifikasi sampel UiO-66 yang telah disintesis.Pola difraksi sinar-X dari UiO66yang telah dilaporkan oleh Abid dkk.[3] dan Cavka dkk. [4]memiliki puncak karakteristik yang muncul pada $2 \theta=7,4 ; 8,5 ; 14,1 ; 14,7 ; 17$ dan $25,6^{\circ}$, dengan dua puncak tertinggi yang khas yaitu puncak difraksi yang muncul pada $2 \theta=7,4$ dan $8,5^{\circ}$. Hal ini menunjukkan bahwa doping $\mathrm{Ni}(\mathrm{II})$ pada sintesis UiO-66 secara solvotermal dengan modulator asam 
format tidak menyebabkan perubahan struktur kristal secara signifikan dari material UiO-66 itu sendiri.Pelebaran puncak pada difraktogram XRD serta penurunan intensitas puncak difraksi teramati pada padatan hasil sintesis Ni-UiO-66 dengan penambahan modulator 100 eq HCOOH.Pelebaran puncak dan turunnya intensitas puncak dapat mempengaruhi kristalinitas dari padatan tersebut.

Puncak difraksi karakteristik yang dimiliki $\mathrm{Ni}\left(\mathrm{NO}_{3}\right)_{2} \cdot 6 \mathrm{H}_{2} \mathrm{O}$ yang berada pada $2 \theta$ sekitar $46^{\circ}$ (tidak ditampilkan) tidak tampak pada difraktogram (Gambar 1) tersebut. Hal ini menunjukkan bahwa Ni telah terkoordinasi dalam kerangka MOF dan tidak terdapat sisa reaktan $\mathrm{Ni}$ dalam padatan hasil sintesis.Tingkat kristalinitas dari suatu senyawa dapat dilihat dari perbedaan intensitas puncak difraktogram dari masing-masing hasil sintesis.

Perhitungan derajat kristalintas dilakukan sesuai dengan metode perhitungan yang dilakukan oleh Venna dkk.[15] dengan cara membandingkan antara luas area dibawah puncak dengan luas daerah dibawah puncak yang paling besar. Luas area yang paling besar digunakan sebagai standar untuk menentukan derajat kristalinitas dari masing-masing padatan hasil sintesis. Sesuai Tabel 2, terjadi penurunan derajat kristalinitas seiring meningkatnya jumlah modulator asam format yang ditambahkan dalam sintesis material UiO-66 dan naiknya derajat kristalinitas Ni-UiO-66 setelah penambahan 100 eq $\mathrm{HCOOH}$ dalam sintesis Ni-UiO-66. Penurunan derajat kristalinitas tersebut berhubungan dengan penurunan keteraturan struktur kristal padatan hasil sintesis akibat penambahan modulator asam format pada material UiO-66. Sedangkan derajat kristalinitas terbesar dimiliki oleh Ni-UiO-66 + 100 eq $\mathrm{HCOOH}$ yang berarti bahwa padatan hasil sintesis tersebut memiliki keteraturan struktur kristal terbaik diantara lainnya. Berdasarkan hasil karakterisasi menggunakan XRD dapat disimpulkan bahwa penambahan modulator asam format dan doping $\mathrm{Ni}(\mathrm{II})$ mempengaruhi keteraturan struktur kristal material UiO-66.

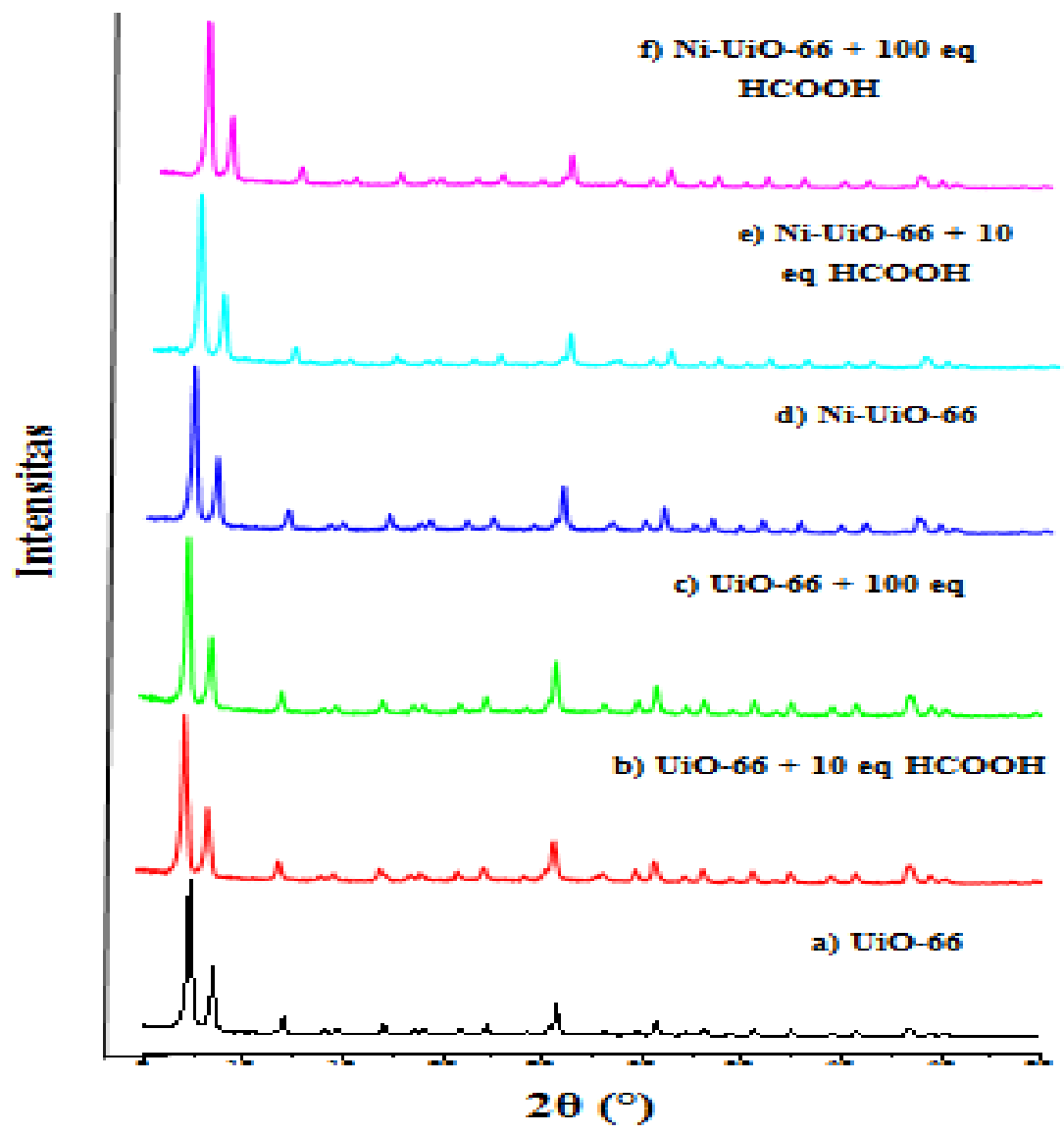

Gambar 1.Difraktogram (a) UiO-66, (b) UiO-66 + 10 eq HCOOH, (c) UiO-66 + 100 eq, (d) Ni-UiO-66, (e) $\mathrm{Ni}-\mathrm{UiO}-66+10$ eq HCOOH, (f) Ni-UiO-66 + 100 eq HCOOH. 
Tabel 2. Puncak karakteristik dan derajat kristalinitas dari material UiO-66 doping $\mathrm{Ni}(\mathrm{II})$ dan penambahan modulator asam format.

\begin{tabular}{|c|c|c|c|c|}
\hline \multirow[b]{2}{*}{ Sampel } & \multicolumn{2}{|c|}{ Sudut $2 \theta\left({ }^{\circ}\right)$} & \multirow{2}{*}{$\begin{array}{c}\sum \text { Luas } \\
\text { area di } \\
\text { bawah } \\
\text { kurva }\end{array}$} & \multirow{2}{*}{$\begin{array}{c}\text { Derajat } \\
\text { kristalinitas } \\
\text { (\%) }\end{array}$} \\
\hline & $\begin{array}{l}\text { Puncak } \\
1\end{array}$ & $\begin{array}{l}\text { Puncak } \\
2\end{array}$ & & \\
\hline UiO-66 & 73,543 & 8,51 & 2778,46 & 99,4 \\
\hline $\begin{array}{l}\text { UiO- } 66+ \\
10 \text { eq } \\
\mathrm{HCOOH}\end{array}$ & 73,855 & 8,51 & 2562,34 & 91,7 \\
\hline $\begin{array}{l}\text { UiO-66 + } \\
100 \text { eq } \\
\text { HCOOH }\end{array}$ & 74,781 & 8,59 & 2076,74 & 74,3 \\
\hline $\begin{array}{l}\text { Ni-UiO- } \\
66\end{array}$ & 74,503 & 8,56 & 2445,65 & 87,5 \\
\hline $\begin{array}{l}\mathrm{Ni}-\mathrm{UiO}- \\
66+10 \\
\text { eq } \\
\mathrm{HCOOH}\end{array}$ & 73,712 & 8,52 & 2175,49 & 77,8 \\
\hline $\begin{array}{l}\mathrm{Ni}-\mathrm{UiO}- \\
66+100 \\
\text { eq } \\
\mathrm{HCOOH}\end{array}$ & 74,853 & 8,61 & 2794,34 & 100 \\
\hline
\end{tabular}

Spektrofotometer Fourier Transform Infrared (FTIR)

Gugus fungsi yang terdapat dalam UiO-66 dan modifikasinyadapat diketahui menggunakan spektroskopi inframerah, sehingga diperoleh informasi mengenai perkiraan struktur molekul yang terbentuk.Pada penelitian ini, hasil karakterisasi
FTIR ditampilkan dalam bentuk kurva bilangan gelombang versus absorbansi atau persen transmitans pada bilangan gelombang $2500-500 \mathrm{~cm}^{-}$

1. Sampel yang dikarakterisasi hanya dipilih empat yang terbaik dari karakterisasi sebelumnya yaitu UiO-66, UiO-66 + 100 eq HCOOH, Ni-UiO-66, dan Ni-UiO-66 + 100 eq HCOOH.

Gugus-gugus fungsi yang muncul pada hasil FTIR yang ditunjukkan pada Gambar 2 diantaranya yaitu pita serapan pada kisaran bilangan gelombang $1400 \mathrm{~cm}^{-1}$ yang merupakan pita serapan milik ikatan $\mathrm{C}-\mathrm{O}$ stretching dari gugus $\mathrm{C}-\mathrm{OH}$ karboksilat. Pita serapan ini muncul pada seluruh padatan hasil sintesis (Gambar 2).

Selain itu, semua padatan hasil sintesis pada bilangan gelombang sekitar $1650 \mathrm{~cm}^{-1}$ muncul pita serapan yang merupakan pita serapan milik $\mathrm{C}=\mathrm{O}$ karboksilat. Pita serapan $\mathrm{C}-\mathrm{O}$ maupun $\mathrm{C}=\mathrm{O}$ dari gugus karboksilat murni muncul pada bilangan gelombang berturut-turut pada kisaran 1320-1210 $\mathrm{cm}^{-1}$ dan 1725-1700 $\mathrm{cm}^{-1}$ [16]. Pergeseran pita serapan $\mathrm{C}=\mathrm{O}$ yang terjadi dimungkinkan karena adanya koordinasi $\mathrm{O}^{-}$dengan logam pusat selama proses deprotonasi [3]. Pita serapan dari $\mathrm{C}=\mathrm{C}$ aromatik dari senyawa benzen muncul pada bilangan gelombang kisaran $1500 \mathrm{~cm}^{-1}$.Cincin aromatik sering muncul pada pita serapan dengan bilangan gelombang antara 1600-1450 cm [16].Pada bilangan gelombang $746,40 \mathrm{~cm}^{-1}$ menunjukkan ikatan Zr-O dari material Zr-BDC (UiO-66). Hal tersebut sesuai hasil analisis Cavka dkk.[4] bahwa framework $\mathrm{Zr}-\mathrm{O}$ muncul pada kisaran gelombang $600-700 \mathrm{~cm}^{-1}$ yang berdekatan dengan dengan vibrasi bending dari $\mathrm{C}-\mathrm{H}$ maupun $\mathrm{O}-$ H.Keseluruhan puncak karakterisasi material secara ringkas ditunjukkan pada Tabel 3.

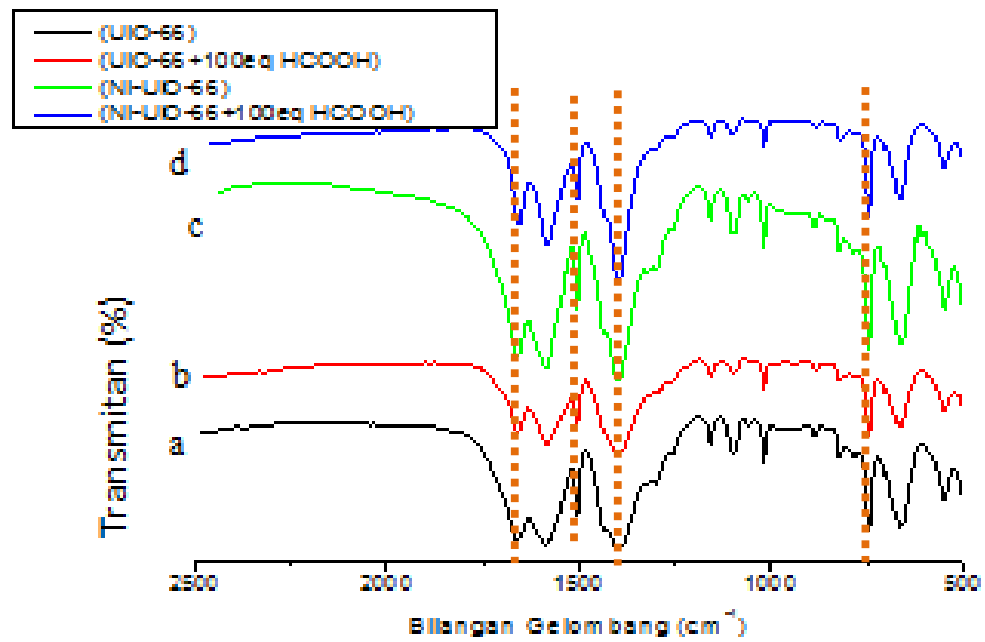

Gambar 2.Spektra FT-IR (a) UiO-66, (b) UiO-66 +100 eqHCOOH, (c) Ni-UiO-66,dan (d) Ni-UiO-66 + 100eq $\mathrm{HCOOH}$ 
Tabel 3. Bilangan gelombang padatan hasil sintesis empat daerah utama.

\begin{tabular}{|l|l|l|}
\hline \multirow{4}{*}{ Material } & $\begin{array}{c}\text { Bilangan } \\
\text { Gelombang } \\
\left(\mathbf{c m}^{-1} \mathbf{)}\right.\end{array}$ & \multicolumn{1}{|c|}{ Jenis Ikatan } \\
\hline \multirow{4}{*}{ UiO-66 } & 1396,37 & C-O dari C-OHkarboksilat \\
\cline { 2 - 3 } & 1504,37 & C=C aromatik \\
\cline { 2 - 3 } & 1654,81 & C=O stretcing \\
\cline { 2 - 3 } & 746,40 & Zr-O framework \\
\hline \multirow{4}{*}{$\begin{array}{l}\text { UiO-66 }+ \\
\text { HCO eq }\end{array}$} & 1400,22 & C-O dari C-OH karboksilat \\
\cline { 2 - 3 } & 1506,3 & C=C aromatik \\
\cline { 2 - 3 } & 1658,67 & C=O stretcing \\
\cline { 2 - 3 } & 746,40 & Zr-O framework \\
\hline \multirow{4}{*}{$\begin{array}{l}\text { Ni-UiO- } \\
66\end{array}$} & 1398,3 & C-O dari C-OH karboksilat \\
\cline { 2 - 3 } & 1508,23 & C=C aromatik \\
\cline { 2 - 3 } & 1656,74 & C=O stretcing \\
\cline { 2 - 3 } & 746,40 & Zr-O framework \\
\hline \multirow{3}{*}{$\begin{array}{l}\text { Ni-UiO- } \\
66+100 \\
\text { eq } \\
\text { HCOOH }\end{array}$} & 1402,15 & C-O dari C-OH karboksilat \\
\cline { 2 - 3 } & 1506,3 & C=C aromatik \\
\cline { 2 - 3 } & 1658,67 & C=O stretcing \\
\cline { 2 - 3 } & 746,40 & Zr-O framework \\
\hline
\end{tabular}

Pengaruh doping $\mathrm{Ni}(\mathrm{II})$ dan penambahan modulator asam format ditunjukkan pada bilangan gelombang kisaran $1500 \mathrm{~cm}^{-1}$, dimana puncak semakin menyempit ketika dilakukan doping $\mathrm{Ni}$ (II) dan penambahan modulator asam format.
Kesimpulan dari hasil analisis FT-IR ini yaitu seluruh padatan hasil sintesis memiliki pita serapan karakteristik yang dimiliki material UiO-66 dan terjadi sedikit pergeseran maupun penyempitan puncak diakibatkan oleh doping $\mathrm{Ni}$ (II) dan penambahan modulator asam format saat disintesis. Namun penambahan tersebut tidak mempengaruhi munculnya pita serapan baru atau gugus fungsi baru dari hasil padatan yang telah disintesis..

Scanning Electron Microscope- Energy Dispersive X-ray (SEM-EDX)

Karakterisasi menggunakan Scanning Electron Microscopy- Energy Dispersive X-Ray (SEMEDX)bertujuan untuk mengetahui morfologi permukaan dan ukuran kristal dariUiO-66, UiO-66 +100 eq $\mathrm{HCOOH}$, dan Ni-UiO-66 serta Ni-UiO-66 +100 eq $\mathrm{HCOOH}$.

Morfologi dari sampel UiO-66 ditunjukkan pada Gambar 3 (a) sedangkan Gambar 3 (b) menunjukkan morfologi dari sampel Ni-UiO-66. Kedua sampel tersebut secara kasat mata berbentuk serbuk putih halus yang kemudian setelah dikarakterisasi menggunakan SEM menghasilkan bentuk morfologi seperti kristal kecil yang bergerombol. Sementara itu pada Gambar 3 (b dan c) setelah penambahan modulator asam format, bentuk morfologinya berubah menjadi partikel besar berbentuk serpihan-serpihan dengan bentuk yang beragam. Perbedaan tersebut menunjukkan bahwa penambahan modulator asam format dapat merubah morfologi UiO-66 dan Ni-UiO-66 menjadi lebih besar.

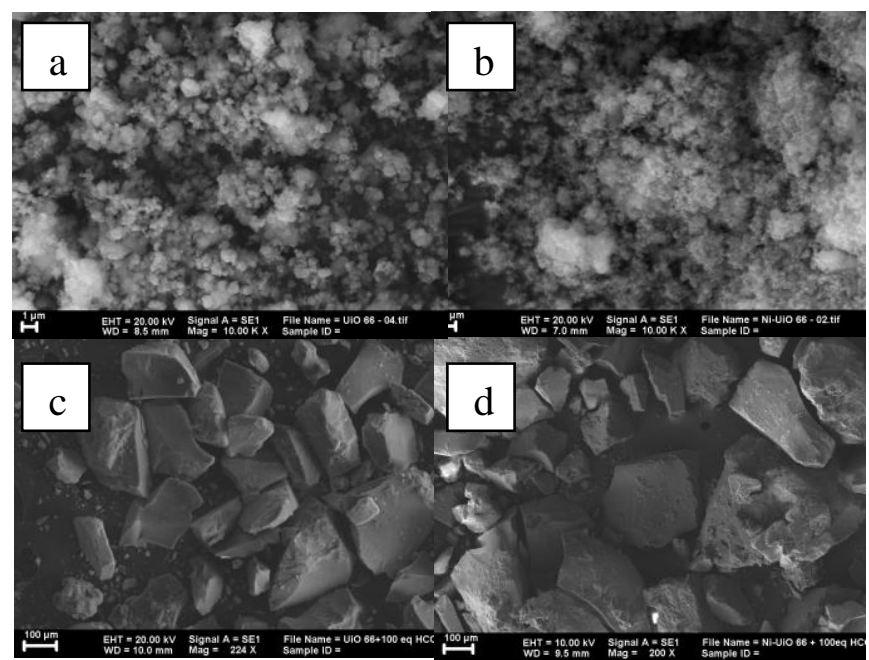

Gambar 3. Hasil SEM Material Padatan (a) UiO-66, (b) Ni-UiO-66, (c) UiO-66 + 100eq HCOOH, dan (d) $\mathrm{Ni}-\mathrm{UiO}-66+100 \mathrm{eq} \mathrm{HCOOH}$ 
Unsur-unsur penyusun padatan hasil sintesis dapat diketahui menggunakan SEM-EDX yang dinyatakan dalam satuan persen berat (\%berat). Berdasarkan unsur penyusun padatan hasil sintesis maka yang diperoleh dapat diketahui pula pengaruh doping $\mathrm{Ni}$ (II) dan penambahan asam format pada kerangka UiO-66. Jika keberadaan logam Ni dalam padatan hasil sintesis $\mathrm{Ni}-\mathrm{UiO}-66$ terdeteksi dalam satuan \%berat maka dapat dipastikan bahwa $\mathrm{Ni}$ telah berhasil tergabung dalam kerangka UiO-66 membentuk Ni-UiO-66.Penambahan modulator asam format juga dapat diketahui dengan bertambahnya satuan \%berat dari unsur $\mathrm{H}, \mathrm{C}, \mathrm{O}$, namun pada hasil SEM-EDX ini tidak ditampilkan keberadaan dari unsur $\mathrm{H}$ dan $\mathrm{C}$ dari padatan hasil sintesis. Presentase unsur-unsur penyusun padatan hasil sintesis dapat diamati pula pada Tabel 4.

Tabel 4. Perbandingan \%berat unsur-unsur penyusun dari masing-masing padatan hasil sintesis.

\begin{tabular}{|l|l|l|l|l|}
\hline Sampel & $\begin{array}{c}\text { Unsur } \\
\text { Zr (\% } \\
\text { berat) }\end{array}$ & $\begin{array}{c}\text { Unsur } \\
\mathbf{N}(\% \\
\text { berat) }\end{array}$ & $\begin{array}{c}\text { Unsur } \\
\text { O (\% } \\
\text { berat) }\end{array}$ & $\begin{array}{l}\text { Unsur } \\
\text { Ni (\% } \\
\text { berat) }\end{array}$ \\
\hline UiO-66 & 12,82 & 59,44 & 27,74 & 0 \\
\hline $\begin{array}{l}\text { UiO-66 + } \\
100 \text { eq } \\
\text { HCOOH }\end{array}$ & 24,30 & 43,09 & 32,60 & 0 \\
\hline $\begin{array}{l}\text { Ni-UiO-66 } \\
\text { + 100 eq } \\
\text { HCOOH }\end{array}$ & 42,52 & 5,21 & 49,07 & 1,36 \\
\hline
\end{tabular}

Pengaruh penambahan modulator asam format $(\mathrm{HCOOH})$ pada material UiO-66 dapat diketahui dengan adanya kenaikan persentase keberadaan unsur $\mathrm{O}$ pada UiO-66 + 100 eq $\mathrm{HCOOH}$ dari yang awalnya 27,74 \% berat menjadi 32,60 \% berat. Hal ini menunjukkan bahwa asam format berada pada kerangka padatan UiO-66 +100 eq $\mathrm{HCOOH}$. Doping $\mathrm{Ni}(\mathrm{II})$ pada material UiO-66 + 100 eq $\mathrm{HCOOH}$ terbukti berhasil dilakukan dengan adanya persentasi keberadaan unsur $\mathrm{Ni}$ yang terdeteksi sebesar 1,36 \%berat. Hal tersebut menunjukkan bahwa Ni(II) berhasil tersubstitusi ke dalam kerangka padatan hasil sintesis.

Thermal Gravimetric Analyzer (TGA)

Karakterisasi menggunakan Thermal Gravimetric Analysis (TGA) berguna untuk mengetahui stabilitas termal dan $\%$ pengurangan berat akibat terdekomposisinya senyawa dalam padatan hasil sintesis pada rentang suhu tertentu.Kurva yang dihasilkan berupa kurva penurunan \%berat senyawa dalam cuplikan (mg) terhadap kenaikan suhu $\left({ }^{\circ} \mathrm{C}\right)$.Kurva termogravimetri (garis hitam) dan kurva differensial termagravimetri (garis merah) dari padatan hasil sintesis ditunjukkan pada Gambar 4.Termogram dari masing-masing padatan hasil sintesis menunjukkan adanya tahapan pengurangan berat $(\mathrm{mg})$ yang berbeda seiring dengan kenaikan suhu. Termogram pada Gambar 4 terdapat 2 tahapan pengurangan berat UiO-66 (a) dan 3 tahapan pengurangan berat $\mathrm{UiO}-66+100 \mathrm{eq}$ $\mathrm{HCOOH}$ (b), Ni-UiO-66 (c), dan Ni-UiO-66 + 100 eq $\mathrm{HCOOH}(\mathrm{d})$. Presentase pengurangan berat dari masing-masing hasil sintesis ditunjukkan pada Tabel 4.

Berdasarkan tahapan pengurangan berat yang ditunjukkan pada termogram (Gambar 4) dan data massapadatan yang hilang pada rentang suhu tertentu (Tabel 5), maka dapat diperkirakan jenis senyawa apa yang hilang dari padatan hasil sintesis. Dengan demikian stabilitas termal hasil padatan dapat diketahui.

Pada tahap pertama, terdapat pengurangan berat di rentang suhu $<100{ }^{\circ} \mathrm{C}$. Pengurangan berat tersebut menunjukkan terjadinya penguapan kloroform yang tersisa dalam kerangka UiO-66. Selanjutnya pengurangan berat pada tahap kedua terletak pada suhu antara $100-300{ }^{\circ} \mathrm{C}$ yang merupakan pengurangan berat dari material organik yaitu evaporasi dari pelarut DMF. Hal tersebut sesuai dengan penelitian yang dilakukan oleh Abid dkk. [3], Zhao dkk. [2], dan Ren dkk. [10].

Pengurangan berat yang signifikan dari masing-masing padatan hasil sintesis terjadi pada kisaran suhu $434-550 \quad{ }^{\circ} \mathrm{C}$ dimana terjadi dekomposisi ligan organik dan runtuhnya struktur UiO-66 membentuk $\mathrm{ZrO}_{2}$.

Kurva pengurangan berat hampir linier pada kisaran suhu $350-500{ }^{\circ} \mathrm{C}$, keterangan tersebut mengindikasikan bahwa pada suhu tersebut stabilitas termal hasil padatan sintesis berada.Ketika padatan tidak mampu lagi mempertahankan kerangkanya, maka disaat itulah titik stabilitas termal dari padatan hasil sintesis dicapai.Stabilitas termal dari masing-masing padatan hasil sintesis (Tabel 5) menunjukkan nilai yang berbeda-beda namun masih dalam rentang 350-500 ${ }^{\circ} \mathrm{C}$.Stabilitas termal bergantung pada kuat-lemahnya ikatan antara ligan dengan logam.Doping $\mathrm{Ni}$ dan penambahan modulator asam format menyebabkan penurunkan stabilitas termal dari UiO-66.Menurunnya stabilitas termal ini diperkirakan karena menurunnya fungsi ligan untuk mengikat logam. 

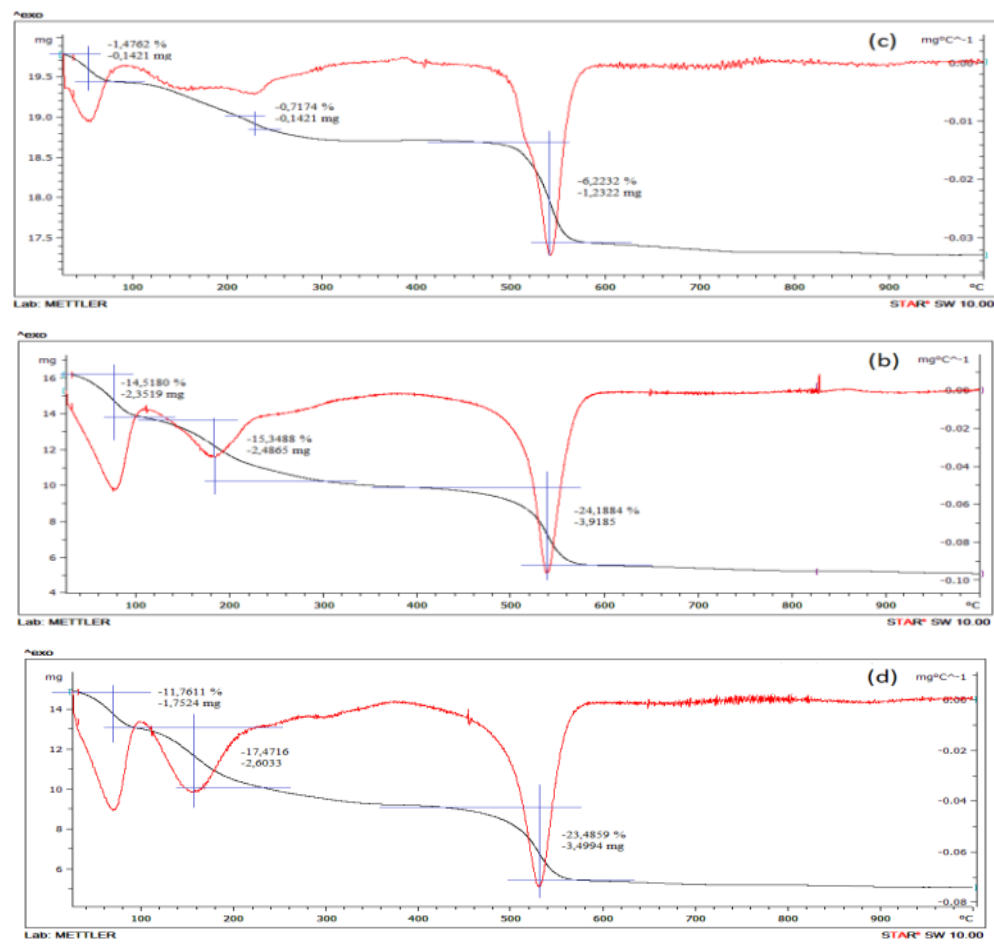

Gambar 4. Kurva TGA-DTA material (a) UiO-66, (b) Ni-UiO-66, (c) UiO-66 + 100eq HCOOH dan (d) NiUiO-66 + 100eq HCOOH.

\section{Adsorpsi-Desorpsi Isotermal Nitrogen}

Analisis adsorpsi-desorpsi isotermal nitrogen digunakan untuk mengetahui luas permukaan dan ukuran pori sampel. Adsorpsi-desorpsi isotermal $\mathrm{N}_{2}$ melalui metode BET (Brunauer, Emmet dan Teller).Metode HK (Horvath-Kawazoe) digunakan untuk mengetahui distribusi pori ukuran mikro. Kurva adsorpsi-desorpsi isotermal nitrogen padatan hasil sintesis UiO-66, Ni-UiO-66, UiO-66 + 100 eq $\mathrm{HCOOH}$, dan Ni-UiO-66 + 100 eq $\mathrm{HCOOH}$ ditunjukkan pada Gambar 5.

Kurva adsorpsi-desorpsi isotermal padatan UiO-66 hampir sama dengan Ni-UiO-66, kemudian setelah penambahan modulator asam format (c dan d) kurva mengalami peningkatan volume adsorpsidesorpsi $\mathrm{N}_{2}$. Hal tersebut menunjukkan bahwa penambahan modulator asam format dapat meningkatkan volume $\mathrm{N}_{2}$ yang teradsorp. Pada Gambar 5 menunjukkan bahwa pada tekanan $\mathrm{P} / \mathrm{Po}=$ 0,01 gas $\mathrm{N}_{2}$ mulai teradsorp.

Gambar 5 menunjukkan bahwa pada tekanan $\mathrm{P} / \mathrm{Po}=0,01$ gas $\mathrm{N}_{2}$ mulai teradsorp. Kemudian setelah tekanan relatif dinaikkan, terjadi adsorpsi nitrogen lebih banyak dan setelah itu hampir linier atau dengan kata lain jumlah gas yang teradsorp hampir sama. Adsorpsi tersebut merupakan adsorpsi nitrogen ke dalam pori berukuran mikro pada lapisan monolayer. Hal tersebut dapat dilihat pada kurva isotermal UiO-66, Ni-UiO-66, UiO-66 + 100 eq $\mathrm{HCOOH}$, dan Ni-UiO-66 + 100 eq $\mathrm{HCOOH}$ pada tekanan $\mathrm{P} / \mathrm{Po}>0,1$, jumlah gas nitrogen yang teradsorp tidak mengalami kenaikan yang signifikan (linier). Begitu pula saat desorpsi dilakukan, loop histerisis akibat fenomena kondensasi pipa kapiler juga tidak terjadi, tetapi yang terjadi adalah jumlah gas $\mathrm{N}_{2}$ yang terdesorp sama dengan gas $\mathrm{N}_{2}$ yang teradsorp pada $\mathrm{P} / \mathrm{Po}=0-1$. Berdasarkan uraian tersebut dapat disimpulkan bahwa padatan UiO-66, Ni-UiO-66, UiO-66 + 100 eq HCOOH, dan Ni-UiO-

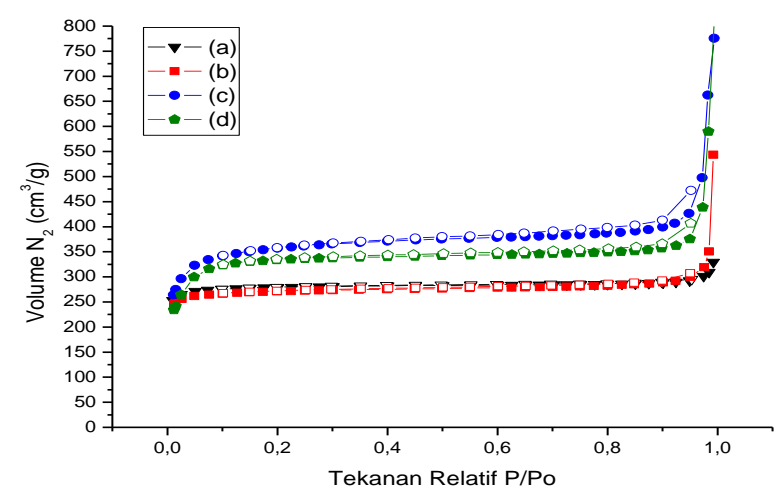

Gambar 5. Adsorpsi-desorpsi isotermal nitrogen 
UiO-66 (a), Ni-UiO-66 (b), UiO-66 + 100eq $\mathrm{HCOOH}$ (c), Ni-UiO-66 + 100eq HCOOH (d).

$66+100$ eq $\mathrm{HCOOH}$ memiliki kurva isotermal tipe I yang merupakan ciri dari padatan dengan ukuran pori mikro yang dominan dengan luas permukaan UiO-66, Ni-UiO-66, UiO-66 + 100 eq $\mathrm{HCOOH}$, dan Ni-UiO-66 + 100 eq $\mathrm{HCOOH}$ berturut turut sebesar $841,299,819,983,1106,848,1020,433 \mathrm{~m}^{2} / \mathrm{g}$. Doping $\mathrm{Ni}(\mathrm{II})$ menyebabkan adanya kompetisi logam $\mathrm{Zr}$ dan $\mathrm{Ni}$ untuk berikatan dengan $\mathrm{O}$ sehingga mengakibatkan turunnya luas permukaan pada $\mathrm{Ni}$ UiO-66, sedangkan penambahan modulator asam format dapat meningkatkan luas permukaan UiO-66 menjadi $1106,848 \mathrm{~m}^{2} / \mathrm{g}$ sesuai penelitian yang dilakukan oleh Ren dkk. (2014).

Distribusi ukuran pori dapat dilihat dari data distribusi ukuran pori yang ditentukan dengan metode HK (Horvath-Kawazoe). Distribusi ukuran pori UiO-66, Ni-UiO-66, UiO-66 + 100 eq $\mathrm{HCOOH}$, dan Ni-UiO-66 + 100 eq $\mathrm{HCOOH}$ ditunjukkan pada Gambar 6.

Keempat kurva tersebut menunjukkan distribusi ukuran mikropori partikel UiO-66, NiUiO-66, UiO-66 + 100 eq HCOOH, dan Ni-UiO-66 +100 eq $\mathrm{HCOOH}$. Puncak yang tampak pada kurva tersebut menginformasikan bahwa ukuran pori sekitar 0,6 nm merupakan ukuran pori terbanyak dalam material tersebut. Jika dilihat dari tinggi puncaknya, urutan volume pori padatan hasil sintesis berturut-turut yaitu Ni-UiO-66 $+100 \mathrm{eq}$ $\mathrm{HCOOH}>\mathrm{UiO}-66+100$ eq $\mathrm{HCOOH}>\mathrm{Ni}-\mathrm{UiO}-$ $66>$ UiO-66. Hasil luas permukaan volume pori, dan ukuran pori UiO-66, Ni-UiO-66, UiO-66 + 100 eq $\mathrm{HCOOH}$, Ni-UiO-66 +100 eq $\mathrm{HCOOH}$ ditunjukkan pada Tabel 5.

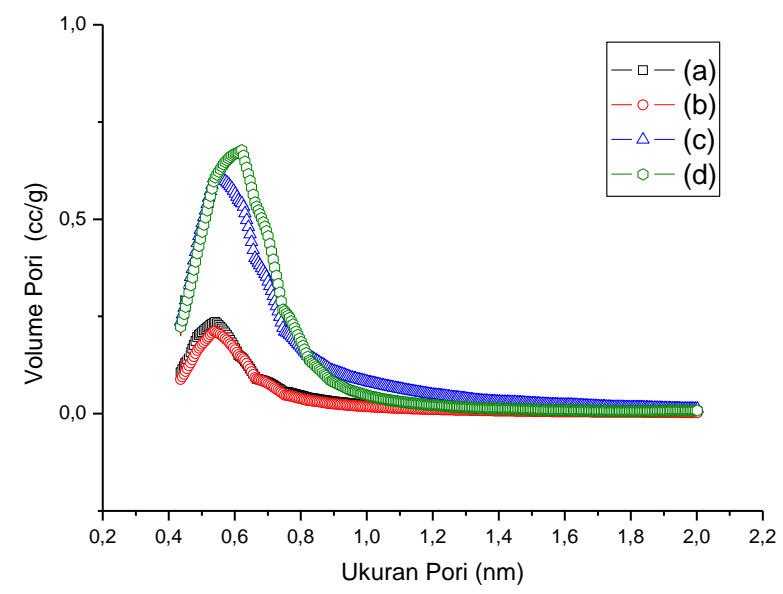

Gambar 6. Distribusi ukuran pori (a) Ni-UiO-66 (b)
UiO-66 (c) UiO-66 + 100eq HCOOH (d) Ni-UiO-66 + 100 eq $\mathrm{HCOOH}$.

Tabel 5.Data Karateristik Pori Material Hasil Sintesis

\begin{tabular}{|l|l|l|l|}
\hline Material & $\begin{array}{c}\text { Luas } \\
\text { Permukaan } \\
\text { BET }\left(\mathbf{m}^{2} / \mathbf{g}\right)\end{array}$ & $\begin{array}{c}\text { Volume } \\
\text { Pori } \\
\left(\mathbf{c m}^{\mathbf{3}} \mathbf{g}\right)\end{array}$ & $\begin{array}{l}\text { Diameter } \\
\text { Pori }(\mathbf{n m})\end{array}$ \\
\hline UiO-66 & 841,299 & 0,212 & 0,432 \\
\hline Ni-UiO-66 & 819,983 & 0,235 & 0,432 \\
\hline $\begin{array}{l}\text { UiO-66 }+ \\
100 \text { eq } \\
\text { HCOOH }\end{array}$ & 1106,848 & 0,606 & 0,432 \\
\hline $\begin{array}{l}\text { Ni-UiO-66 } \\
+100 \text { eq } \\
\text { HCOOH }\end{array}$ & 1020,433 & 0,678 & 0,432 \\
\hline
\end{tabular}

\section{Kesimpulan}

Sintesis UiO-66 dengan doping 10\% Ni(II) telah berhasil dilakukan dengan menggunakan metode sintesis solvotermal pada suhu $120^{\circ} \mathrm{C}$ selama 24 jam dengan dan tanpa menggunakan modulator asam format. Difraktogram XRD semua padatan hasil sintesis memiliki dua puncak utama pada sudut $2 \theta=7,4^{\circ}$ dan $8,5^{\circ}$ sesuai dengan difraktogram UiO-66 standar yang mengindikasikan bahwa tidak ada perubahan struktur kristal UiO-66 pada masing-masing padatan hasil sintesis.Penambahan modulator asam format dan dopingNi(II) mempengaruhi kristalinitas material UiO-66 menjadi lebih kristalin. Spektra FTIR menunjukkan pita-pita serapankarakteristik yang dimiliki material UiO-66. Foto SEM menunjukkan bahwa penambahan modulator asam formatmenghasilkan morfologi yang lebih besar.Hasil adsorpsi-desorpsi $\mathrm{N}_{2}$ menunjukkan bahwa luas permukaan BET meningkat menjadi $1020,433 \mathrm{~m}^{2} / \mathrm{g}$ setelah doping $\mathrm{Ni}$ (II) dan penambahan modulator asam format. Namun doping $\mathrm{Ni}$ (II) dan penambahan modulator asam format mengakibatkan penurunan stabilitas termal pada material UiO-66 menjadi $434{ }^{\circ} \mathrm{C}$.

\section{Ucapan Terimakasih}

Penulis mengucapkan terima kasih kepada Direktorat Jenderal Pendidikan Tinggi, Kementrian Pendidikan dan Kebudayaan Republik Indonesia atas dana yang telah diberikan melalui Hibah Penelitian Unggulan 
Institut Teknologi Sepuluh Nopember (ITS), Ucapan terimakasih juga disampaikan kepada Laboratorium Energi ITS dan Laboratorium Fundamental serta Laboratorium Kimia Material dan Energi Jurusan Kimia FMIPA ITS atas semua fasilitas yang telah diberikan untuk terlaksananya penelitian ini.

\section{Daftar Pustaka}

[1] Kuppler R. J., Timmons, Daren J., Fang Q. -R., Li J. -R., Makal T. A., Young M. D., Yuan D., Zhao D., Zhuang W., Zhou H. -C. (2009). Review: Potential application of metal organic framework. Coordination Chemistry Reviews 253, 3042-3066.

[2] Zhao Q., Yuan W., Liang J. and Li J. (2013) Synthesis and hydrogen storage studies of metal-organic framework UiO-66. International Journal of Hydrogen Energy, 1-6.

[3] Abid, H.R., Tian, H., Ang, H-M., Tade, M.O., Buckley, C.E., Wang, S., (2012). "Nanozise ZrMetal Organic Framework (UIO-66) for Hydrogen and Carbon Dioxide Storage". Chemical Engineering Journal 187, 415-420.

[4] Cavka J.H., Jakobsen S., Olsbye U., Guillou N., Lamberti C., Bordiga S., Lillerud K.P. (2008). A new zirconium inorganic building brick forming metal organic frameworks with exceptional stability. Journal of the American Chemical Society130, 13850-13851.

[5] Low J.J., Benin A.I., Jakubczak P., Abrahamian J.F., Faheem S.A., Willis R.R. (2009). Journal of the American Chemical Soiety131, 15834-15842.
[6] Chuah G. K., Liu S. H., Jaenicke S., Harrison L. J. (2001) Cyclisation of Citronellal to Isopulegol Catalysed by Hydrous Zirconia and Other Solid Acids. Journal of Catalysis200, 352-359.

[7] Vermoortele F., Ameloot R., Vimont A., Serre C., De Vos D. (2011) An amino modified Zrterephthalate metal organic framework as an acid base catalyst for cross aldol condensation. Chemical Communications47, 1521-1523

[8] Timofeeva M. N., Panchenko V. N., Jun J. W., Hasan Z., Matrosova M. M. and Jhung S. H. (2014) Effects of linker substitution on catalytic properties of porous zirconium terephthalate UiO-66 in acetalization of benzaldehyde with methanol. Applied Catalysis A: General 471, 91-97.

[9] Li, J., Cheng, S., Zhao, Q., Long, P., Dong, J., (2009). "Synthesis and Hydrogen - Storage Behavior of Metal-Organic Framework MOF-5". International Journal of Hydrogen Energy 34, 1377-1382.

[10] Ren, J., Langmi, H.W., North, B.C., Mathe, M., Bessarabov, D., (2014). "Modulated Synthesis of Zirconium-Metal Organic Framework (Zr-MOF) for Hydrogen Storage Applications". International Journal of Hydrogen Energy 39, 890-895.

[11] Lee, S-Y., Park, S-J., (2011). "Effect of Platinum Doping of Activated Carbon on Hydrogen Storage Behaviors of Metal-Organic Frameworks-5". International Journal of Hydrogen Energy 36, 8381-8387. 
